\title{
Connection of Teachers' Organizational Commitment and Transformational Leadership. A Case Study from Greece
}

\author{
Kouni Zacharo \\ Secondary Education Professor, M.Ed. in Educational Management
}

Koutsoukos Marios

Ass. Professor, ASPETE, School of Pedagogical and Technological Education

Panta Dimitra

Professor, ASPETE, School of Pedagogical and Technological Education

\begin{abstract}
In the international literature there are many documented studies which have shown the connection between leadership and commitment to organization. Specifically, transformational leadership is highly associated with this important and positive work attitude, job satisfaction. The interpretation in a school context is that the director should practice as transformational leader so as to produce better educational outcomes through teachers' commitment to school goals. In Greece, little empirical research has been done to investigate the perceptions of teachers about the connection between transformational leadership and organizational commitment. The purpose of the present study is to investigate the perceptions of teachers to the extent that transformational leadership contributes to commitment to school goals. The selected research method is a combination of quantitative and qualitative methods, namely using questionnaire and interview. The sample consisted of 171 teachers from two types of educational institutions, lower and upper general secondary schools of a local administration of secondary education. The survey's results showed that teachers feel substantial commitment to school goals when the school principal acts as transformational leader. Demographic variables, type of school and work experience, do not affect the views of teachers.
\end{abstract}

Keywords: leadership; transformational leadership; organizational commitment. 


\section{Introduction}

School leadership shares common features with leadership that is applied to non-educational environments (Unesco, 2016), with the process of the individual-leaders' exertion of influence over other individuals or groups playing a central role (Pont, Nusche \& Moorman, 2008; Bush \& Glover, 2003; Bourantas, 2005), so that, by activating and guiding the latter to work willingly, the school's objectives can be effectively achieved (Saitis, 2008).

Effective schools require sound leadership and management, working in harmony, unison, and complementary one to the other ( Bush \& Bell, 2003; Stachteas, 2016) In this context, the principal, in his or her role as a leader, manages and disseminates innovation and change, always in direct contact with the school's teachers (Kampouridis, 2010; Stachteas, 2016).

Research data highlight the potential of transformational leadership to contribute towards the improvement of schooling conditions, assist in the development of the teachers' skills, as well as have a positive impact on the attitude and behavior of teachers, who are expected to voluntarily adopt behaviors that will help in achieving the school's goals, making a greater effort and staying with the school (Cohen \& Caspary, 2011; Leithwood \& Jantzi, 1999a; Kushman 1992; Somech \& Bogler, 2002).

\section{Theoretical context of transformational leadership}

A transformational leader inspires his or her followers to commit to a common vision and goals, also challenging them to adopt innovative thinking in problem solving, as well as advising, guiding, and supporting them, in order to develop leadership skills (Bass et al., 2014). This helps them to consider the vision as a reflection of their own values, rather than something that is imposed on them. It also enables them to develop their self-efficacy and contribute to the implementation of the organization's goals (Kanungo, 2001). As a result, followers feel admiration, trust, loyalty, and respect towards the leader. They are also motivated to perform better than expected, and demonstrate a high sense of duty, along with emotional commitment to their job, strong incentives to succeed, and a willingness to look beyond their personal interest and look after the welfare of the group to which they belong (Bass, 1997; Tosi et al., 2000; Yukl, 1999).

Tichy and Ulrich (1984) stress the fact that there three key processes of transformational leadership that make it effective in managing change within an organization: the development of a vision, the motivation for commitment, and the incorporation of change within the operation of the organization. In specific, a transformational leader should first develop a new vision for the organization for the future. This vision will provide direction and orientation for the organization towards a desirable future situation, as well as comply with the philosophy espoused by the leader and organization (Zavlanos, 1998, 2003; Tichy et al., 1984). After that, the organization should become familiar and accept its new mission and vision, and that is the reason why the leader communicates with the other members, in order to ensure support on both a 
personal and collective level (Tichy et al., 1984). The last process that refers to incorporation will show whether a reform will actually take place, since, in this stage, the leader will convert the vision into reality, mission into activity, and philosophy into action, establishing thus a new culture within the organization (Hersey, Blanchard \& Jonson 1996; Zavlanos, 2003; Tichy et al., 1984 ).

\section{Theoretical context of organizational commitment}

From the longitudinal studies that have been conducted on the subject of organizational commitment, three main theoretical approaches have been developed in three different periods: calculative approach, psychology approach and multidimensional approach (Cohen, 2013. Cohen, 2007, WeiBo, Kaur \& Jun, 2010), and they are outlined as follows:

\subsection{The calculative approach (1st period)}

The calculative approach is based on the Side-bets theory, which was developed by Becker (1960), who describes commitment as the individual's intention to follow a "consistent lines of activity" (p. 32), as a result of the concentration of Side-bets, which will be lost, if the action is stopped (Meyer \& Allen, 1984).

The Side-bets refer to anything that is of major importance to the individual, and in which, the individual has invested time, effort, and/or money, which will be lost or lose their value, if the individual leaves the organization (Wallace, 1997; Meyer et al., 1984). When the individual is employed by an organization, consistent lines of activity refer to the individual's wish to stay with the organization, in order to maintain the Side-bets (Ghosh et al., 2014; Meyer et al., 1984).

The Side-best are associated with the income, status, seniority in service, and social connections that were built as a result of the individual's stay with the organization. Therefore, the risk of losing them, along with the lack of alternatives to replace or substitute them, causes the individual's commitment towards the organization (Cohen, 2013).

\subsection{The psychology approach (2nd period)}

According to Porter et al., in order to interpret organizational commitment, there is a shift of interest from tangible Side-bets to the individual's psychological attachment to the organization (Cohen, 2007; Ghosh et al., 2014). They describe organizational commitment as the individual's focused attitude in identifying with and involvement in the organization, and more specifically, to the extent that the individual's values and goals comply with those promoted by the organization (Porter, Steers, \& Bulian, 1973; Porter, Steers, Mowday \& Bulian, 1974; Mowday et al., 1982; Mowday et al.,1979).

Under these conditions, organizational commitment is characterized by three relevant factors: strong belief in and acceptance of the organization's goals, standards, and values by the individual, loyalty, as the individual's decision to remain a member of the organization, and the individual's participation, showing the individual's wish to contribute voluntarily more towards the organization's optimum operation (Cohen, 2014; Ghosh et al., 2014; Mowday et 
al., 1982; Mowday et al., 1979; Porter et al., 1974). Hence, loyalty is not passive, as it involves the individual's active connection with the organization, which is reflected in the individual's wish to contribute towards the latter's prosperity (Mowday et al., 1982; Mowday et al., 1979).

\subsection{The multidimensional approach (3rd period)}

The multidimensional approach is the evolution of the unidimensional approach to organizational commitment of the above psychology approach, with two key multidimensional approaches, one by O'Reilly \& Chatman, and the other by Meyer \& Allen (Ghosh et al., 2014; Cohen, 2007).

In the theory developed by O'Reilly et al. (1986), building on the work of Kelman on the shift in attitudes and behaviors, organizational commitment is interpreted as the individual's psychological attachment to the organization, which can be predicted by three independent factors: compliance, identification, and internalization (Kelman, 1958; Meyer et al., 1997; O'Reilly et al., 1986; WeiBo et al., 2010).

Compliance results from the individual's adoption of behaviors, in order to earn external rewards and acceptance and avoid penalties or rejection for noncompliance with the organization. On the other hand, identification results from the individual's adoption of behaviors, in order to maintain desirable connections within the organization, and internalization is the result of the individual's adoption of behaviors, due to the fact that the values of the organization correspond to those embraced by the individual.

The theoretical multidimensional approach of Meyer et al. (1997) is the most predominant one for research studies that refer to organizational commitment (Jaros, 2009, Mercurio, 2015, WeiBo et al, 2010). It compiles three different definitions that have been provided for organizational commitment into three more general ones, according to which, the individual's commitment to the organization is regarded as "reflecting emotional orientation towards the direction of the organization, along with the recognition of the cost that is associated with the departure from the organization, and the moral obligation to remain with the organization" (Meyer et al., 1997, p. 11).

Based on these definitions, Meyer et al. (1997) created a model for organizational commitment, which consists of three elements: affective commitment, normative commitment, and continuance commitment, arguing that all three types of commitment are evident, to a certain extent, in the connections of the individual with the organization (Meyer et al., 1997, 1991). Affective, normative, and continuance commitment are described as follows:

- Affective commitment. It refers to the commitment that is caused, because the individual is "emotionally attached to, identifies with, and is involved in the organization" (Meyer et al., 1997, p. 11, Meyer \& Allen, 1991, p. 67). Affective commitment increases when the individual agrees with the values and goals of the organization, and stays with it, in order to assist in the achievement of the 
latter's mission, as a result of the individual's free will to do so (Greenberg et al., 2013; Meyer et al., 1997, 1991; Mercurio, 2015). The affective organizational commitment of Meyer and Allen corresponds conceptually to the approach of Porter et al. (1974) on organizational commitment, as well as to the identification and internalization of O'Reilly et al. (1986) (Fornes \& Rocco, 2004; Morrow, 1993).

- Normative commitment. It refers to the commitment that is caused, because the individual feels obliged to stay with the organization. The stronger is the individual's commitment, the more the individual feels obliged to continue to work as an employee at the same organization (Meyer et al., 1997, 1991). The individual feels obliged to stay with the organization, because it believes that this is morally right, and not because this serves the individual's goals (Pinder, 2008). Furthermore, an individual with a high level of normative commitment assigns importance to the emotions and negative thoughts of others around it, in case it decided to leave the organization (Greenberg et al., 2013).

- Continuance commitment. It refers to the commitment that is caused, because the individual feels obliged to stay with the organization, by estimating the cost of leaving (Vakola et al., 2012; Meyer et al., 1997, 1991). The more the individual stays with the organization, the more its commitment grows. This is because the individual believes that, by leaving the organization, there is a greater risk to lose what it has invested during its employment with the organization (Greenberg et al., 2013).

In this context, and in order to reach the objective of this study, organizational commitment will be interpreted as an attitude, through which, the individual largely trusts and accepts the goals and values of the organization, and wishes to remain its member, in order to assist in the achievement of those goals for the organization's benefit (Mowday et al., 1982).

\section{The organizational commitment of teachers}

In public schools, the type of organizational commitment that was defined by Mowday et al. (1982) and affective commitment of Meyer et al. (1997) reflects the sense of loyalty that is experienced by the teacher towards the organization/school that he or she works for, as well as the teacher's identification with the school's values and goals (Hodge \& Ozag, 2007, Kushman, 1992, Nir, 2002).

In general, the organizational commitment of teachers has been treated as a multidimensional concept by researchers. The teachers' commitment to the school that they work at is one of the numerous dimensions that they can develop, such as their commitment to help students learn (Geijsel et al., 2002; Ibrahim, Ghavifekr, Ling, Siraj \& Azeez, 2014; Firestone \& Penel, 1993; Kushman, 1992; Louis, 1998; Nir, 2002), their commitment to the profession and their professional development, in order to acquire new knowledge and skills (Geijsel et al., 2002; Louis, 1998; Rauf, Akhtar, Asim \& Islam, 2003), and their commitment to the academic achievement of students (Firestone et al., 1993, 
Louis, 1998; Nir, 2002; Rauf et al., 2003). Regarding the teachers' commitment, in any dimension that it may take, it has been recognized by the scholars and researchers who have studied it, that it contributes to the school's potential for modernization and transformation (Geijsel et al., 2002; Leithwood, 1994).

In recent surveys on the teachers' commitment to the school, it has been shown that it affects:

- their willingness to support the necessary changes that are promoted in schools. A strong commitment by the teacher towards the school where he or she works at has an equally strong impact on his or her decision to be involved in educational reforms (Cohen et al., 2011).

- their organizational citizenship behavior. The stronger the teacher's commitment to the school, the more willing the teacher is to help those who need it, i.e. younger colleagues, students both inside and outside school hours, and the school community in general (Cohen \& Liu, 2011; Sesen \& Basim, 2012; Somech et al., 2002).

- their performance. The teacher's commitment to the school helps him or her to improve his or her professional performance. This includes the teacher's teaching skills, willingness to conduct research, personal skills, initiative, and overall presence at school (Cohen et al., 2011; Chughtai et al., 2006).

- their job satisfaction. When a teacher feels strong commitment towards the school organization, then the teacher experiences job satisfaction, and as result, he or she improves his or her work (Rauf et al., 2003).

Other surveys show that the organizational commitment of the teacher is affected by:

- the job satisfaction. When the teacher experiences job satisfaction, then he or she can cover his or her needs and develop a strong psychological connection-commitment with the school, enhancing the quality of the provided knowledge and supporting the efforts of his or her students for better learning results (Anari, 2012; Rauf et al., 2003).

- a team-cooperative workplace environment. The sense of the teacher's commitment towards the school grows, when there is communication among teachers, as well as cooperation, support to the teaching work, and participation in the school's management (Dee, Henkin \& Singleton, 2006; Iordanidis, Tsakiridou \& Sagiadinou, 2014; Somech et al., 2002).

self-efficacy \& self-esteem. Teachers who demonstrate a high level of selfefficacy \& self-esteem and feel competent to correspond to various situations, are more emotionally committed to their school (Izzati, Suhariadi \& Hadi, 2016).

- the school's culture and values. The school culture and values that exist within the organization affect the degree of the teacher's emotional identification with the school. (Finegan, 2000; Karadac, Baloglu \& Cakir, 2011).

- trust and expectations. The teacher's trust in the school and leadership, as well as his or her expectations that he or she has the ability to deal with the change that takes place at school, strengthens his or her commitment to the organization (Hodge et al., 2007). 
The connection between transformational leadership and the teachers'
organizational commitment A transformational leader can have a strong influence on the attitudes of the members of the organization, and their commitment towards himself or herself and the organization, serving as a role model that has adopted and adheres steadfastly to the organization's goals and values (Bass et al., 2014). He or she focuses on developing the readiness and responsibility of all the members, so that the school's goals can become a jointly accepted "contract" that morally binds leadership and teachers (Sergiovanni, 1991). He or she provides loyal support towards the progress of the members of the organization, and manages to strengthen their commitment to the organization (Ross \& Gray, 2006).

Notwithstanding the fact that there has been limited research interest on the connection between transformational leadership and the teachers' commitment to their school, there are remarkable findings (Eliophotou et al., 2016; Khasawneh, Omari \& Abu-Tineh, 2012; Nguni et al., 2006).

Noraazian \& Khalip (2016) conducted a quantitative survey on a sample of 317 teachers from primary education schools in Malaysia. The investigated the impact of transformational leadership on the teacher's commitment to their schools, and found out that the high level of transformational leadership practices undertaken by school principals had a significant impact on the teachers' commitment.

In a survey conducted by Sayadi (2016) on a sample of 387 teachers from 42 schools across all levels of education about the influence of the leadership style on the job satisfaction and organizational commitment, it was demonstrated that the higher the level of the leader's idealized influence-talent (the leader serves as a role model of ethical behavior and earns the teachers' admiration, respect, and trust), the higher is the level of the teachers' job satisfaction and organizational commitment.

In another quantitative survey on a sample of 235 secondary education teachers in Malaysia, which was conducted by Raman, Mey, Don, Daud \& Khalid (2015), it was shown that there is a significant connection between transformational leadership and the teachers' commitment to their schools. Moreover, in an earlier survey on 1,014 trainee undergraduate and graduate teachers in secondary education from 27 schools, which was conducted by Ibrahim et al. (2014), it was illustrated that there is crucial correlation between transformational leadership and the teachers' commitment towards the organization, the teaching profession, and the students.

In 2014, Kieres \& Gutmore (2014) conducted a quantitative survey in Pennsylvania, USA, on a sample of 156 secondary education teachers about the added value of transformational leadership practices to job satisfaction and organizational commitment. The survey showed that the idealized influence and personalized care are the characteristics of a transformational leader that have the strongest impact on the teachers' commitment and job satisfaction. In this 
line, the leader is a role model for ethical behavior, and earns the teachers' admiration, respect, and trust. He or she also shows that he or she cares about teachers, offering them opportunities for personal and professional development and acting as a mentor. Furthermore, in a survey conducted by Feizi, Ebrahimi \& Beheshti (2014) on a sample of 196 secondary education teachers in Iran, it was shown that idealized influence is the characteristic of a transformational leader that has the strongest influence on organizational commitment.

Additionally, in a meta-analysis of twenty surveys in Turkey, which was conducted by Aydin et al. (2013), in order to investigate the influence of the leadership style on the teachers' organizational commitment and job satisfaction, it was demonstrated that transformational leadership also has a positive influence on organizational commitment and job satisfaction. More specifically, as the principal's leadership style changes from transactional to transformational, the level of job satisfaction and organizational commitment also rises.

Further to that, Khasawneh et al. (2012) explored the link between transformational leadership and the teachers' commitment to their school. They used a survey of 340 vocational education teachers from 66 teachers in Jordan, and it was shown that there is a strong, positive, and statistically significant connection between transformational leadership and the teachers' commitment to their school. In specific, the leadership traits that are more strongly correlated to commitment are inspirational motivation, individualized consideration and intellectual stimulation.

\section{Research methodology}

\subsection{Research objective}

The relevant empirical surveys that have been conducted on the role of the transformational leader/school principal in the teachers' organizational commitment are very limited in Greece. This survey aims to contribute to the discussion about the influence of transformational leadership on the teachers' organizational commitment.

More specifically, it aims to investigate the views of teachers about the connection between transformational leadership and their commitment to the goals of the school where they serve.

\subsection{Research questions}

It was attempted to provide answers to the following research questions:

1. To what extent do teachers believe that transformational leadership contributes to organizational commitment?

2. Are views divided over whether transformational leadership contributes to organizational commitment according to the years of previous experience?

3. Are views divided over whether transformational leadership contributes to organizational commitment according to the type of school? 


\subsection{Sample}

The sample of quantitative survey consisted of secondary junior high schools and high schools teachers from Eastern Thessaloniki. 171 teachers participated, 72 of whom serve in junior high schools (a percentage rate of $42 \%$ ), and 99 in high schools (a percentage rate of $58 \%$ ). In order to conduct the qualitative survey, interviews were taken from 10 permanent teachers who serve at secondary and high schools, where the quantitative survey was conducted.

\subsection{The questionnaire}

The questionnaire of the survey included three sections of questions:

a) The first section contained 2 questions relating to the size and type of the school unit (secondary or high school).

b) The second section contained 5 questions relating to demographic data (gender, age, qualifications, employment connections, overall teaching experience) of the subjects of the sample, and

c) The third section contained 27 question-statements, which refer to the behaviors and practices of the transformational leaders in teaching, and which may affect the teachers' commitment to the school's goals. The questionstatements are closed-ended and marked against a grading scale from $1=$ to a minimum extent, to $5=$ to a very large extent.

\subsection{The interview}

The interview was structured on three thematic axes:

1st thematic axis: personal details of the responding teacher

2nd thematic axis: exploring the views about the general behaviors of the male or female school principal that contribute to the teacher's organizational commitment

3rd thematic axis: exploring the views about the most important behaviors of the male or female school principal that contribute to the teacher's organizational commitment

\subsection{Research validity and reliability}

Research validity and reliability were ensured, first of all, through the use of a multi-method approach (triangulation). Additionally, a higher content validity of the questions and their reliability and better adaptation to the operating context of the Greek school (Cohen, Manion \& Morisson, 2008) were ensured by a pilot application of the questionnaire to subjects who were not going to participate in the final survey. The final survey was conducted between March and April 2017, and the statistical processing of data was performed with the SPSS 20 statistical package, which is the most appropriate one for social data and surveys that are conducted by using a questionnaire (Dafermos, 2011). In all the statistical tests of hypotheses for generalization over the population, a maximum error possibility of $a=0.05$ or $5 \%$ was determined as significance level of the test (Jacobson, 1976). Each hypothesis would be rejected if possibility P (p-value) was lower than 0.05 .

With regard to the reliability and consistency of the questionnaire, the Cronbach's alpha reliability and internal consistency coefficient was required. It was found that alpha $=0.972$ ( $\mathrm{N}=27$ questions). The values are quite high and 
satisfactory. Therefore, it is confirmed that no positive and negative correlations occur at the same time. Regarding whether it was necessary to exclude a question from the questionnaire, in order to increase the value of alpha, which is something extremely detailed compared to its original value, no significant increase was identified due to excluding a question, and in most of them, the coefficient was lower or extremely close to the total (Field, 2009).

In order to practically ensure a degree of validity for the interview, it was attempted to reduce any causes of bias by recording the views of the respondents, as they were expressed, and without looking for answers that would support the predispositions of the researchers (Cohen et al., 2008). The reliability of the interview was pursued through the structured nature of the questions asked to all the respondents, without any changes in the verbal expression of the questions or the use of emphasis (Cohen et al., 2008). Moreover, the reliability of the interviews was supported by testing and confirming the qualitative research data provided by the male/female participants (Symeou, 2006).

\subsection{Utility of research}

The survey highlights the teachers' views about the connection between transformational leadership and organizational commitment and aspires to contribute to the scientific discussion about it. Moreover, research findings can be utilized in designing further training programs for school unit principals, in order to help them act as transformational leaders, and teachers in general, who need to develop leadership skills, either as leaders in their classroom or mentors to their colleagues.

\subsection{Presentation and analysis of results}

\subsubsection{Demographic-personal data}

$42.1 \%$ of the 171 teachers who participated in the survey serve at secondary schools, whereas $57.9 \%$ of them serve at high schools, with males being relatively less than males, at $36.8 \%$ versus $63.2 \%$, respectively. In terms of the employment connection, an overwhelming proportion of $98.2 \%$ of the teachers are permanent at the schools. The majority of teachers have many years in education, and this finding shows that teachers have prior experience from working with at least one school principal, as well as from the leadership behaviors and practices that may cause, or not, job satisfaction commitment at school.

\subsubsection{Descriptive characteristics of the level of organizational commitment}

The responding teachers recorded their views in 27 question-statements of second level about the level of organizational commitment. This was followed by the calculation of the mean value for each respondent. The mean value was found to be $4.22 \pm 0.71(\mathrm{~N}=169)$. Even if the two answers that still missed were replaced by some mean value, the mean value of all the answers would be infinitesimally affected. Therefore, the mean value is higher than the theoretical central value 3 and reaches $84.4 \%$ of absolute commitment. Furthermore, a minor standard deviation is observed in the responses, i.e. $s=0.71$, which lower than 1, and therefore, responses are extremely concentrated close to the "view" 
that is determined by their mean value that refers to a high level of commitment, standing at 4.22 (Table 1 ).

Table 1: 5.9.2 Descriptive characteristics of the level of organizational commitment

\begin{tabular}{|l|l|l|l|l|}
\hline $\mathrm{N}$ & Mean value & Standard & Minimum & Maximum \\
\hline 169 & 4.22 & 0.71 & 1.11 & 5.00 \\
\hline
\end{tabular}

5.8.3 Differences in the level of organizational commitment within the sample The investigation of the differences in the indicators that reflect the contribution of transformational leadership to the teacher's commitment towards the school's goals, compared to the characteristics of the sample, did not yield any statistically significant differences among the categories of any variable expressed by the sample. More specifically, there were not any statistically significant differences in the organizational commitment between secondary and high school teachers. This conclusion can be drawn from the t-test for the indicator that refers to the mean value, where it was found out that $\mathrm{p}=0.856>0.05$ $(\mathrm{t}=0.181$, d.f. $=166, \mathrm{~N} 1=97, \mathrm{~N} 2=71)$ with equal dispersions from Levene's test $(p=0.418>0.05)$. Therefore, the minor difference in mean values is not regarded as statistically significant, and therefore, regardless of the school type (secondary or high school), the teachers stated approximately the same mean value of organizational commitment in the questionnaire (Tables 2, 3).

Table 2: Organizational commitment with regard to the school unit type

\begin{tabular}{|l|l|l|l|}
\hline School Unit Type & $\mathrm{N}$ & Mean value & Standard Deviation \\
\hline High School & 97 & 4.21 & 0.74 \\
\hline Secondary School & 71 & 4.23 & 0.68 \\
\hline
\end{tabular}

Table 3: Criterion of equality of dispersions and Correlation of the mean values with organizational commitment with regard to the school unit type through $\mathbf{t}$-test

\begin{tabular}{|l|l|l|l|l|l|}
\hline & \multicolumn{2}{|l|}{ Levene's Test on Equality of } & t-test \\
\hline School Unit Type & $\mathrm{F}$ & $\mathrm{p}$ & $\mathrm{t}$ & d.f. & $\mathrm{p}$ \\
\hline $\begin{array}{l}\text { Assumed Equality of } \\
\text { Dispersions }\end{array}$ & 0.660 & 0.418 & -0.181 & 166 & 0.856 \\
\hline Note. ${ }^{*} \mathrm{p}=0.856>0.05$, two-tailed. & \multicolumn{5}{l}{} \\
\hline
\end{tabular}

In terms of the overall teaching service of the respondents, descriptive table 4 illustrates a greater deviation in organizational commitment as a result of the application of transformational leadership, in the category of total teaching service over 29 years, i.e. in relatively older teachers, compared to other categories.

Table 4: Organizational commitment with regard to total teaching service (Years)

\begin{tabular}{|l|l|l|l|}
\hline Total Teaching Service (Years) & $\mathrm{N}$ & Mean value & Standard Deviation \\
\hline$<12$ & 22 & 4.40 & 0.62 \\
\hline $12-17$ & 41 & 4.22 & 0.74 \\
\hline $18-23$ & 40 & 4.22 & 0.74 \\
\hline $24-29$ & 33 & 4.15 & 0.61 \\
\hline$>29$ & 32 & 4.16 & 0.82 \\
\hline Sums & 168 & 4.22 & 0.71 \\
\hline
\end{tabular}


In order to identify possible statistically significant differences among the categories of service, Levene's homogeneity test of fluctuations was performed, where, under null hypothesis, dispersions are equal, and was found that $p=0.612<0.05$ ( $F=0.673$, d.f. $1=4$, d.f. $2=163$ ), and therefore, the homogeneity of fluctuations in service categories is rejected (Tables 5, 6).

Table 5: Criterion of homogeneity of fluctuations about the commitment to goals with regard to total teaching experience

\begin{tabular}{|l|l|l|l|}
\hline Levene's F & d.f.1 & d.f.2 & $p$ \\
\hline 0.673 & 4 & 163 & 0.612 \\
\hline \multicolumn{2}{|l}{ Note. ${ }^{*} \mathrm{p}=0.612>0.05$, two-tailed. } \\
\hline
\end{tabular}

Table 6: ANOVA analysis of variances among and within the categories of teaching service about the commitment to goals

\begin{tabular}{|l|l|l|l|l|l|}
\cline { 2 - 6 } \multicolumn{1}{c|}{} & ANOVA & Mean Square MS & F & p \\
\cline { 2 - 6 } \multicolumn{1}{c|}{} & Sum of Squares & d.f. & Metwe & 0.512 & 0.727 \\
\hline Between & 1.054 & 4 & 0.263 & & \\
\hline Within & 83.864 & 163 & 0.514 & & \\
\hline Total & 84.914 & 167 & & & \\
\hline
\end{tabular}

Results of the interviews

The key findings of the interviews confirm the findings of the quantitative survey and focus on seven conceptual axes of the questionnaire: building a common vision, accepting common goals, developing high performance expectations, providing personalized support, igniting mental stimulation, serving as a role model and providing values, and building partnerships and cooperations.

\section{Conclusion}

The data analysis leads a number of results, which compose the responses provided to the research questions.

Regarding the first research questions i.e. to what extent do teachers believe that transformational leadership contributes to their commitment to the school's goals, it is evident that this happens to a very high extent. The same conclusion is drawn in earlier surveys, which highlighted the strong influence of transformational leadership on secondary education teachers' commitment to school (Sayadi, 2016; Raman, Mey, Don, Daud \& Khalid, 2015; Ibrahim, Ghavifekr, Ling, Siraj \& Azeez, 2014; Kieres et al., 2014; Feizi, Ebrahimi \& Beheshti, 2014; Aydin et al., 2013), with the factor "Provision of individualized support" having the highest positive contribution to commitment (Kieres et al., 2014; Khasawneh, Omari \& Abu-Tineh, 2012). Transformational leadership plays a connective role between the teachers and the principal in building, accepting, and pursuing common and high-level goals, which fit within the overall context of official educational policy. Teachers are emotionally committed to the school's goals, when the leader encourages discussion and deliberately promotes cooperation towards the implementation of the goals, providing constructive feedback on an equal basis, and taking into account the personality and needs of teachers. 
Regarding the second research question, i.e. whether views differ about the assumption that transformational leadership contributes to organizational commitment depending on the school type, the survey showed that the views do not differ. This is a view that is not supported by literature citations in other recent empirical surveys. In this survey, teachers from both school types believe that a transformational leader is the appropriate person to align their collective responsibility with their responsibility as individuals, in order for them to coexist and cooperate on commonly accepted goals, by taking specific forms of action. Each teacher has different values, beliefs, incentives, goals, and ambitions. A transformational leader shows his or concern to understand diversity, in order to be able to earn the teacher's trust and commitment, as well as motivate him or her to change and improve his or her teaching work through cooperation, always focusing on the implementation of challenging yet feasible goals (Eliophotou \& Ioannou, 2016, Leithwood et al., 1999b).

Finally, regarding the third research question, i.e. whether views differ about the assumption that transformational leadership contributes to organizational commitment depending on the total teaching service, the survey showed that the views do not differ. This is a view that is not supported by literature citations in any other recent empirical surveys. In this survey, teachers, regardless of age, perceive the practices and behavior of a transformational leader as effective in enhancing their commitment to the school's goals. This means that they incorporate a specific vision, towards the achievement of which, the leader works persistently and methodically, aiming to set mutually acceptable goals, within the context of implementing the vision, and ensuring everyone's affective commitment to these goals (Leithwood, Jantzi \& Steinbach, 1999b; Theofilidis, 2012) . A transformational leader establishes the appropriate climate, within which, everything is openly and honestly discussed, in order to achieve a balance between the challenge and support towards the implementation of improvement and innovation. This, however, should not be taken as personal questioning of the teacher's values and abilities (Leithwood et al., 1999b; Wasserberg, 1999).

\section{Acknowledgements}

The authors would like to thank the fellow male and female teachers who participated in the survey and accepted to fill in the questionnaire, showing great willingness to express their views in the interviews. Also, the authors would like to thank the reviewers and the editor of this journal for their valuable comments on an earlier version of this manuscript.

\section{References}

Anari, N.N. (2012). Teachers: emotional intelligence, job satisfaction, and organizational commitment. Journal of Workplace Learning, 24 (4), 256-269. https://doi.org/10.1108/13665621211223379

Aydin, A., Sarier, Y., \& Uysal, S. (2013). The Effect of School Principals' Styles on Teachers' Organizational Commitment and Job Satisfaction. Educational Sciences. Theory \& Practice, 13(2), 806-811. 
Bass, M.B. (1997). From Transactional to Transformational Leadership: learning to Share the Vision. In R.P. Vecchio (Ed), Leadership. Understanding the Dynamics of Power and Influence in Organizations (pp.318-333). Notre Dame, IN: University of Notre Dame Press.

Bass, B. M., \& Riggio, R. E. (2014). Transformational leadership (2nd ed.). New York: Routledge

Becker, S.H. (1960). Notes on the concept of commitment. The American Journal of Sociology, 66 (1), 32-40.

Bourantas, D. (2005). Leadership-The path to ongoing success. Athens: Kritiki, (in Greek)

Bush, T., \& Bell, L. (2003). The Policy Context. In T. Bush \& L Bell (Eds), The principles and practice of educational management (pp. 3-14). London: PCP

Bush, T., \& Glover, D. (2003). School Leadership: Concept and Evidence. UK: NCSL. Available at http://dera.ioe.ac.uk /5119 /14/dok217-eng-School_Leadership_ Concepts_and_Evidence_Redacted.pdf. (15/3/2017)

Chughtai, A.A., \& Zafar, S. (2006). Antecedents and Consequences of Organizational Commitment Among Pakistani University Teachers. Applied Human Resource Management Research, 11 (1), 39-64.

Cohen, A. (2007). Commitment before and after: An evaluation and reconceptualization of organizational commitment. Human Resource Management Review, 17, 336-354.

Cohen, A., \& Caspary, L. (2011). Individual Values, Organizational Commitment, and Participation in a Change: Israeli Teachers' Approach to an Optional Educational Reform. Journal of Business and Psychology, 26, 385-396.

Cohen, A., \& Liu, Y. (2011). Connections between in-role performance and individual values, commitment, and organizational citizenship behavior among Israeli teachers. International Journal of Psychology, 46 (4), 271-287.

Cohen, L., Manion, L., \& Morisson, K. (2008). Methodology of educational research (trans. S. Kyranakis, M. Mavraki. C. Mitsopoulou, P. Bithara \& M. Filopoulou). Athens: Metaichmio

Dafermos, V. (2011), Social statistics and Research methodology with SPSS, Thessaloniki: Ziti

Dee, R.J., Henkin, B. A., \& Singleton, A.C. (2006). Organizational Commitment of Teachers in Urban Schools. Examining the Effects of Team Structures. Urban Education, 41(6), 603-627.

Eliophotou- Menon, M., \& Ioannou, A. (2016). The link between transformational leadership and teachers' job satisfaction, commitment, motivation to learn, and trust in leader. Academy of Educational Leadership Journal, 20 (3), 12-22. ISSN 10956328

Feizi, M., Ebrahimi, E., \& Beheshti, N. (2014) Investigating the connection between transformational leadership and organizational commitment of high school teachers in Germi. International Journal of Organizational Leadership, 3, 17-30.

Field, A., (2009). Discovering Statistics using SPSS (3rd ed.). London: Sage Publications, Inc.

Finegan, E.J. (2000). The impact of person and organizational values on organizational commitment. Journal of Occupational and Organizational Psychology, 73, 149-169.

Firestone, A.W., \& Rosenblum, S. (1988). Building Commitment in Urban High Schools. Educational Evaluation and Policy Analysis, 10 (4), 285-299.

Fornes, L.S., \& Rocco, S.T. (2004). Commitment Elements Reframed (Antecedents and Consequences) for Organizational Effectiveness. Florida International University, 19 (3), 391-397. 
Geijsel, F., Sleegers, P., Leithwood, K., \& Jantzi, D. (2002). Transformational leadership effects on teachers' commitment and effort toward school reform. Journal of Educational Administration, 41(3), 228-256

Ghosh, S., \& Swamy, D.R. (2014). A Literature Review on Organizational CommitmentA Comprehensive Summary. International Journal of Engineering Research and Applications, 4 (12), 4-14.

Greenberg, J., \& Baron, A.R. (2013). Organizational psychology and behavior (trans. A.-S. Antoniou). Athens: Gutenberg

Hersey, P., Blanchard, H.K., \& Jonson. E.D. (1996). Management of organizational behavior (7th ed.). Englewood Cliffs, N.J.: Prentice Hall

Hodge, M.E., \& Ozag, D. (2007). The Connection between North Carolina Teachers Trust and Hope and Their Organizational Commitment. The Delta Pi Epsilon Journal, 49 (2), 128-139.

Ibrahim, S.M., Ghavifekr, S., Ling, S., Siraj, S., \& Azeez, K.I.M. (2014). Can transformational leadership influence on teachers' commitment towards organization, teaching profession, and students learning? A quantitative analysis. Asia Pacific Education Review 15, 177-190.

Iordanidis, G., Tsakiridou, H., \& Sagiadinou, G. (2014). Greek Teachers' Views about Their Organizational Commitment to Primary School. American Journal of Educational Research, 2 (8), 603-611. DOI: 10.12691/education-2-8-8

Izzati, A.U., Suhariadi, F., \& Hadi, C. (2016). The role of self-competence on affective organizational commitment of vocational high school temporary teachers. International Journal of Organizational Innovation, 8 (4), 133-139.

Jacobson, P. (1976). Introduction to Statistical Measures for the Social \& Behavioral Sciences. Hinsdale: Dryden Press.

Jaros, S. (2009). Measurement of commitment. In Klein, H., Becker, T., \& Meyer, J. (Eds.), Commitment in Organizations: Accumulated Wisdom and New Directions (pp. 347-382). New York: Routledge.

Kampouridis, G. (2010). Leadership of Educational Organizations Module notes. Technological Educational Institute of Western Greece, Patra. (in Greek)

Kanungo, N.R. (2001). Ethical Values of Transactional and Transformatioanal Leaders. Canadian Journal of Administrative Sciences, 18 (4), 257-265. https://doi.org/10.1111/j.1936-4490.2001.tb00261.x

Karadac, E., Baloglu, N., \& Cakir, A. (2011). A Path Analysis Study of School Culture and Teachers' Organizational Commitment. Policy Futures in Education 9 (5), 573-584. https://doi.org/10.2304/pfie.2011.9.5.573

Kelman, C. H. (1958). Compliance, identification, and internalization three processes of attitude change. Journal of Conflict Resolution, 2, 51-60.

Khasawneh, S., Omari, A., \& Abu-Tineh, M.A. (2012). The Relationship between Transformational leadership and Organizational Commitment: The Case for Vocational Teachers in Jordan. Educational Management Administration \& Leadership, 40 (4), 494-508. https://doi.org/10.1177/1741143212438217

Kieres, H.K., \& Gutmore, D. (2014). A study of the Value Added by Transformational Leadership Practices to Teachers' Job Satisfaction and Organizational Commitment. Educational Leadership Review of Doctoral Research, 1 (1), 175-184. ISSN: 1532-0723

Kushman, W.J. (1992). The Organizational Dynamics of Teacher Workplace Commitment: A Study of Urban Elementary and Middle Schools. Educational Administration Quarterly, 28 (1), 5-42. 
Leithwood, K. (1994). Leadership for School Restructuring. Educational Administration Quarterly, 30 (4), 498-518.

Leithwood, K., \& Jantzi, D. (1999a). Transformational School Leadership Effects: A Replication. School Effectiveness and School Improvement, 10 (4), 451-479.

Leithwood, K., Jantzi, D., \& Steinbach, R. (1999ß). Changing leadership for changing times. Buckingham: Open University Press.

Louis, S.K. (1998). Effects of Teacher Quality of Work Life in Secondary Schools on Commitment and Sense of Efficacy. School Effectiveness and School Improvement, 9 (1), 1-27.

Mercurio, A.Z. (2015). Affective Commitment as a Core Essence of Organizational Commitment: An Integrative Literature Review. Human Resource Development Review, 14 (4), 389-414. https:// doi.org/10.1177/1534484315603612

Meyer, P.J, \& Allen, J.N. (1984). Testing the "Side-Bet Theory" of Organizational Commitment: some Methodological Considerations. Journal of Applied Psychology, 69 (3), 372-378.

Meyer, P.J, \& Allen, J.N. (1991). A three component conceptualization of organizational commitment. Human Resource Management Review, 1 (1), 61-89.

Meyer, P.J, \& Allen, J.N. (1997). Commitment in the Workplace. Theory, Research and Application. Thousand Oaks, CA: Sage Publications, Inc.

Mowday, T.R., Porter, W.L., \& Steers, M.R. (1982). Employee-organization linkages. The psychology of commitment, absenteeism, and turnover. New York: Academic Press.

Mowday, T.R., Steers, M.R., \& Porter, W.L. (1979). The measurement of Organizational Commitment. Journal of Vocational Behavior, 14, 224-247.

Morrow, C.P. (1993). The theory and measurement of work commitment. Greenwich, CT: JAI Press.

Nguni, S., Sleegers, P., \& Denessen, E. (2006). Transformational and transactional leadership effects on teachers' job satisfaction, organizational commitment, and organizational citizenship behavior in primary schools: The Tanzanian case. School Effectiveness and School Improvement, 17 (2), 145-177. https://doi.org/10.1080/09243450600565746

Nir, E.A. (2002). School-based management and its effect on teacher commitment. International Journal of Leadership in Education, 5 (4), 323-341. https://doi.org/10.1080/13603120210134616

Noraazian, B.O., \& Khalip, M. (2016). The Impact of Transformational leadership and Teacher Commitment in Malaysian Public Schools. International Journal of Academic Research in Business and Social Sciences, 6 (11), 388-397.

O'Reilly, A.C., \& Chatman, J. (1986). Organizational Commitment and Psychological Attachment: The Effects of Compliance, Identification, and Internalization on Prosocial Behavior. Journal of Applied Psychology, 71 (3), 492-499.

Pinder, C.C. (2008). Work motivation in organizational behavior (2nd ed.). New York: Psychology Press.

Pont, B., Nusche D., \& Moorman, H. (2008). Improving school leadership. Volume 1: Policy and Practice. Paris: OECD. Available at: https:// www.oecd.org/edu/school / 44374889.pdf (15/2/2017)

Porter, W.L., Steers, M.R., \& Boulian, V.P. (1973). Organizational commitment, job satisfaction and turnover among psychiatric technicians. Technical Report, 16, 121. 
Porter, W.L., Steers, M.R., Mowday, T.R., \& Boulian, V.P. (1974). Organizational commitment, job satisfaction, and turnover among psychiatric technicians. Journal of Applied Psychology, 59 (5), 603-609.

Raman, A., Mey, H.C., Don, Y., Daud, Y., \& Khalid. (2015). Connection between Principal's Transformational leadership Style and Secondary School Teachers' Commitment. Asian Social Science, 11 (15), 221-228. http://doi.org/10.5539/ass.v11n15p221

Rauf, M., Akhtar, S.M., Asim, M.S., \& Islam, M. (2003). Connection between Organizational Commitment and Job Satisfaction of Teachers Serving as Subject Specialists at Higher Secondary Schools in Khyber Pakhtunkhwa. The Dialogue 8 (2), 144-154.

Ross, A.J., \& Gray, P. (2006). Transformational leadership and teacher commitment to organization values: The mediating effects of collective teacher efficacy. School Effectiveness and School Improvement, 17 (2), 179-199. https://doi.org/10.1080/09243450600565795

Saitis, C. (2008). Organization \& Management of Education (5th ed.) Athens: [without terminology]

Sayadi, Y. (2016). The effect of dimensions of transformational, transactional, and nonleadership on the job satisfaction and organizational commitment of teachers in Iran. Management in Education, 30 (2), 57-65. https://doi.org/10.1177/0892020615625363

Sesen, H., \& Basim, H. N. (2012). Impact of satisfaction and commitment on teachers' organizational citizenship. Educational Psychology, 32 (4), 475-491. https:// doi.org/10.1080/01443410.2012.670900

Somech, A., \& Bogler, R. (2002). Antecedents and Consequences of Teacher Organizational and Professional Commitment. Educational Administration Quarterly, 38 (4), 555-577. https:/ / doi.org/10.1177/001316102237672

Stachteas, C. (2016). The acquisition of a knowledge background in scientific management by school unit principals: Need and prospects. Theory and Research in Education Sciences, 8, 99-114. (in Greek)

Symeou, L. (2006). Validity and reliability in qualitative research: The paradigm of a survey on the cooperation between school-family. Proceedings of the 9 th Conference of the Pedagogical Society of Cyprus, Nicosia, 2nd-3rd of June 2006. Available at http://www.pek.org.cy/proceedings.html (23/3/2017). (in Greek)

Theofilidis, C. (2012). School leadership and management. From Bureaucracy to transformational leadership. Athens: Grigoris (in Greek)

Tichy, M.N., \& Ulrich, O.D. (1984). SMR Forum: The Leadership Challenge-A Call for the Transformational Leader. Sloan Management Review, 26 (1), 59-68.

Tosi, L.H., Mero, P.N., \& Rizzo, R.J. (2000). Managing Organizational Behavior (4th ed.). Cambridge, Mass: Blackwell Publisher Inc.

Unesco. (2016). Leading better learning: School leadership and quality in the Education 2030 agenda. Regional reviews of policies and practices. Paris: UNESCO. Available at: http:/ / www.unesco.org/ new/fileadmin/MULTIMEDIA/HQ/ED/pdf/leadership-report.pdf $(15 / 2 / 2017)$

Wallace, E.J. (1997). Becker's Side-Bet Theory of Commitment Revisited: Is It Time for a Moratorium or a Resurrection? Human Relations, 50 (6), 727-749.

Wasserberg, M. (1999).Creating the Vision and Making it Happen. In H. Tomlison, H. Gunter, E P. Smith (Eds.), Living Headship (pp. 154-165). London: Sage Publications 
Weibo, Z., Kaur, S., \& Jun W. (2010). New Development of Organizational Commitment: A Critical Review (1960-2009). African Journal of Business Management, 4 (1), $12-$ 20. ISSN 1993-8233

Yukl, G. (1999). An Evaluation of Conceptual Weakness in Transformational and Charismatic Leadership Theories. Leadership Quarterly, 10 (2), 285-305.

Vakola, M., \& Nikolaou, I. (2012). Organizational Psychology and Behavior. Athens: Rosili Zavlanos, M. (2003). Total quality in education. (in Greek) Athens: Stamoulis

Zavlanos, M. M. (1998). Management. (in Greek) Athens: Ellin 